\title{
FEEDING PEANUT BUTTER TO BIRDS IN WINTER
}

\section{Ron Jensen}

1027 King Crescent

Saskatoon, SK S7K 0N9

Peanut butter as a winter food provides many benefits to the tough little feathered friends who cheer up our winter days.

I had heard about providing peanut butter many years ago on a television program - perhaps from John Acorn or someone like him. However, there was concern that the peanut butter was too rich and caused problems for our winter friends. A case of a chickadee being found egg bound in the spring, i.e. an egg was stuck in the bird's oviduct, was highlighted. The individual speaking about this on the show had applied a warm compress and massaged the vent area. An egg finally came out with a distinct smell of peanut butter. That person had been feeding peanut butter all winter and thus the cautionary note that winter species feeding heavily

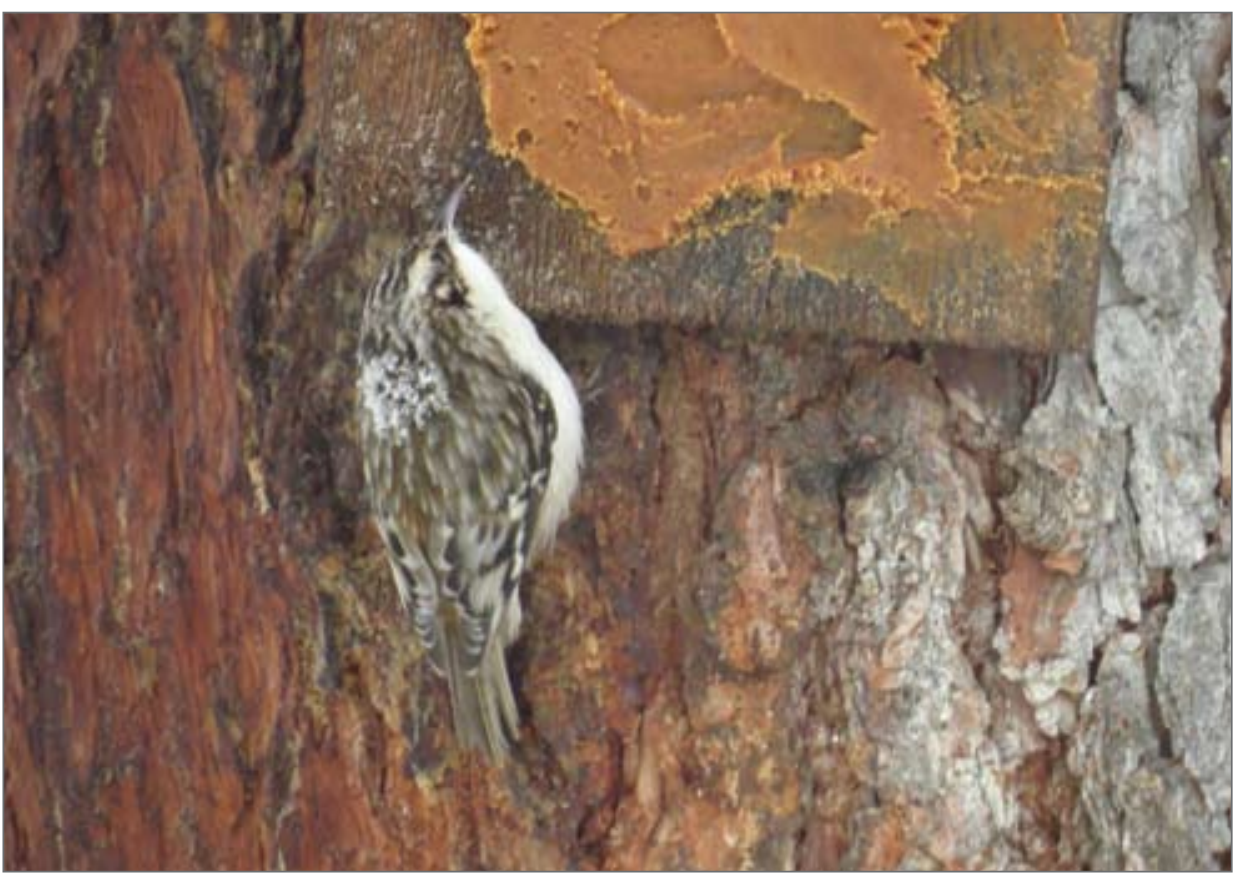

A Brown Creeper feeds on peanut butter slathered on a wooden shingle. Photo credit: Ron Jensen on peanut butter could become egg bound along with the benefits.

Now, fast forward to three winters ago - I purchased a jar of salt-free peanut butter, which required a bit of a searching through product aisles of a least two grocery stores. Depending upon your location, some stores offer selfgrind unsalted peanuts if you are unable to locate unsalted peanut butter. It is important that unsalted peanut butter be purchased to avoid dehydration of the species feeding on the peanut butter.

I spread the peanut butter generously on the bark of two conifers - in the front yard, visible from the dining room table, and in the backyard, which could be viewed out my wife's home office window. The list of interested birds grew quickly: Downy Woodpeckers, Blackcapped Chickadees, Red-breasted and White-breasted Nuthatches, Black-billed Magpies and House Sparrows. The rapid disappearance of the peanut butter, especially on cold winter days or just before a storm, was amazing. Second and third jars were soon consumed.

In the third winter, I got smarter about where to spread the peanut butter. My wife commented that the peanut butter grease stain on the trees didn't seem to disappear. I had thought it would. My solution was to attach a fine wire to two large wooden shingles, generously spread the peanut butter on to them, and then attach each peanut butter slathered shingle to their respective conifer trees. This worked really well because it eliminated House Sparrows, but the Black-billed Magpies were still able to get at one peanut butter feeder by standing on top of the sunflower seed feeder. The solution was to lower the sunflower seed feeder, putting the peanut buttered shingle out of reach.

Now I was happy providing saltfree peanut butter to four species of winter residents. A fifth surprise species appeared - Brown Creepers that could visit at either feeder. What a treat to see a Brown Creeper at any time, but especially during wintertime when a Brown Creeper is considered an "irregular winter visitor." 1

As last winter's feeding time came to a close, there were pairs of the following: Downy Woodpeckers, Red-breasted and White-breasted Nuthatches, Brown Creepers and several Black-capped Chickadees all looking sleek and healthy, ready for a busy season of rearing young.

A.L. Leighton et al ed. 2002. Birds of the Saskatoon Area. Special Publication No. 5 Manley Callin Series Special Publication No. 23 p.225. 